\title{
Chemical Biomarker Study of Negative Physiological Effects of Insecticides on Pakistani Farm Workers Health in the Central Punjab
}

\author{
Muhammad Shahzad, ${ }^{1}$ Atif Yaqub, ${ }^{2}$ Mehmood Shaukat, ${ }^{3}$ Muhammad Kashif Fida, ${ }^{4}$ Nazish Mazhar Ali, ${ }^{5}$ \\ Tanveer Hussain, ${ }^{6}$ Muhammad Sheeraz ${ }^{7}$
}

\begin{abstract}
Background: In recent decades, use of pesticides in agricultural practices has posed threat to human population.

Objectives: Present research was designed to explore the adverse effects of insecticides on 339 individuals (study group farmers $n=256$ and control $n=83$ ) selected from 62 different sites of central Punjab. The sample was matched on socio-economic status and age.
\end{abstract}

Methodology: A structured questionnaire was used to

\footnotetext{
${ }^{1} \mathrm{PhD}$ Student, Department of Zoology

Government College University, Lahore

${ }^{2}$ Assistant Professor of Zoology

Government College University, Lahore

${ }^{3}$ Professor of Paeds Surgery, Principal Allama Iqbal Medical

College/ Jinnah Hospital, Lahore

${ }^{4}$ Assistant Professor of Psychology, Department of Humanities, COMSATS Institute of Information Technology, 1.6 KM-Off

Defence Road, Lahore

${ }^{5}$ Associate Professor, Zoology Department, GCW, Model Town, Lahore

${ }^{6}$ Assistant Professor, Department of Molecular Biology

Virtual University of Pakistan

${ }^{7}$ Hospital Pharmacist, DHQ, Sheikhupura
}

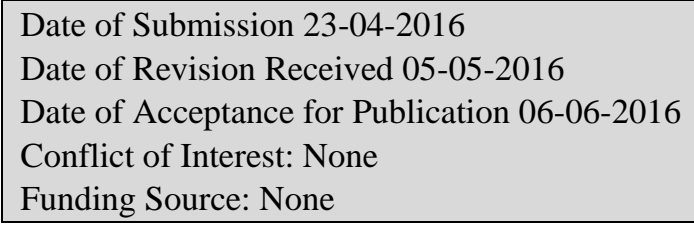

\section{Contribution}

All Authors have contributed in Study Design, Data Collection, Data Analysis, Data Interpretation, Manuscript Writing and Approval. obtain the demographics and pesticide related details. For bio-chemical analysis blood samples were collected from both groups.

Results: Bio-chemical analysis shows that, farmers exposed with pesticide have significant elevated levels of Urea $(p=0.05)$ and alanine transaminase (ALT) $(p=$ $0.01)$ as compared with control. On contrary, low levels of BChE, albumin and total protein (TP) levels ( $p=0.001 ; p=0.05$ and $p=0.001$ respectively) were found in pesticide exposed subjects than controls. Also, significant increase in serum creatinine $(p=$ $0.01)$, aspartate transaminase (AST) $(p=0.01)$ and notable decrease in the albumin, TP and $\operatorname{BChE}(p=$ 0.001) were evident in farmers with poor protective measures. However the statistical difference is not correlated with clinical difference.

Conclusions: Several biomarkers have shown the possible hazards of pesticides to farmer's health than controls. It was further explored that health indicators also associated with other factors like duration of exposure to pesticides, tobacco smoking and poor handling practices amongst the studied population.

Key words: Pesticides, Biomarkers, Environmental toxicology, Public health, Butyrylcholinesterase (BChE) activity, LFT, RFT, practices.

\section{Introduction}

Pesticides are being used extensively in ago - ecosystems to stop or lessen the damages caused by pests and consequently boosting up the quality yield of the agri products. ${ }^{1}$ These chemicals also upgrade the nutria- 
tional worth of food as well. ${ }^{2,3}$ In Pakistan, agricultural products contribute $21 \%$ of the total Gross Primary Productivity (GDP) and pesticide use is on increase as from last 20 years, its usage and number of sprays per crop has been increased by $11.9 \%$ and $10 \%$ respecttively. ${ }^{4}$ According to the 'Economic Survey (2006), alarming situation has developed for the agrarian workers because pesticides usage has risen during 1980 to 1999 from 665 tons to 45,680 tons respectively. At present, a variety pesticide like insecticides, 108 different types; weedicides, 39 types; fungicides, 30 types; agricides, 5 types, and rodenticides, 6 types, are being in use in Pakistan. ${ }^{5}$ It has been reported by many researchers that particulars of the human health impacts depends on pesticide exposure which may be accidental. ${ }^{6-8}$ or occupational. ${ }^{9-11}$

Although pesticides are playing significant role in enhancing crop production to meet the demand of ever - increasing human population but at the same time very harmful to the non-target biota in the vicinity of pesticide use including industrial and agricultural workers.

In the developing countries, exposure to pesticides is considered as a major occupational risk among farmers. ${ }^{12-14}$ The exposure to pesticides may occur due to spillage, improper usage, or non-caring attitude of pesticide handlers. Miss handling of pesticides while transfers may also cause human exposure to pesticides. ${ }^{15}$ For determining health risks during farming practices in underdeveloped countries, dermal exposure to pesticides is of particular interest and it is primarily due to the lack of work - related hygiene policies. ${ }^{16}$

Farm workers that have poor information regarding safety practices and protective measures are more at risk to pesticide exposure. ${ }^{17}$ Chronic low dose exposure to pesticides causes health effects and is very difficult to evaluate as these chemicals are mostly used in the form of a variety of mixtures. . $^{18,19}$

The pesticide residues tend to accumulate in various tissues and subsequently could affect the metabolic system of the body including enzymes. ${ }^{20,21}$ However, some recent studies suggested strong correlation between pesticide exposure and rise in the values of various liver and kidney related enzymes and other factors, such as alanine transaminase (ALT) and aspartate transaminase (AST), alkaline phosphate (ALP), total protein (TP), urea, creatinine, blilirubin, total proteins etc. ${ }^{22-24}$ Kidney and liver functions may be affected due to extended exposure to variety of pesticide. A significant decrease in butyrylcholinesterase (BChE) has been previously observed in humans exposed to pesticides compared to those not exposed..$^{25}$

Different parameters, such as attitude, knowledge and practice about handling of pesticides have direct bearing on pesticide exposure. This necessitates initiation of such studies, particularly in the under developed countries, like Pakistan.

\section{Patients and Methods}

The present study was designed to investigate the fatal effects of commonly used insecticides on the Pakistani farm workers' health in the area of central Punjab. This is basically a chemical biomarker study based on human health concerns. This study has followed expost facto research design with comparison group. In ex-post facto research, researcher compares pre-existing groups (exposed and control) on dependent variables. One group was exposed group comprises of farmers having acquaintance of pesticide spray. The second group comprises of individuals living in same vicinity but not at all exposure to pesticide spray. The study involved the following:

Sample and sampling.

Selection of individual farm workers exposed to insecticides (exposed group).

Selection of matched control (individual with no exposure of pesticide, living in same vicinity as the exposed sample).

Collection of blood samples from the experimental group.

Determination of biochemical parameters of collected blood samples including serum isolation, renal and hepatic enzyme functions, Butyrylcholinesterase $(\mathrm{BChE})$ determination.

Analysis of blood sample results.

The first and important step of study was to select the sites which are exposed to continuous spray of insecticides. A rational was made on the basis of literature that in vegetable (crops like cabbage, brinjal, pea, potatoes) growing areas, more spray needed than other crops. These sites exists in the region of Central Pun-jab (Lahore, Kasur, Sheikhupura and Nankana Sahib, Fig. 2), Pakistan (Fig. 1). A total of 339 individuals (pesticide exposed farmers $n=256$ and control $\mathrm{n}=83$ ) were selected for the study. Fourteen participants withdrew from the research as per their own preference and hence not counted in total sample size. It was purposive sampling. 


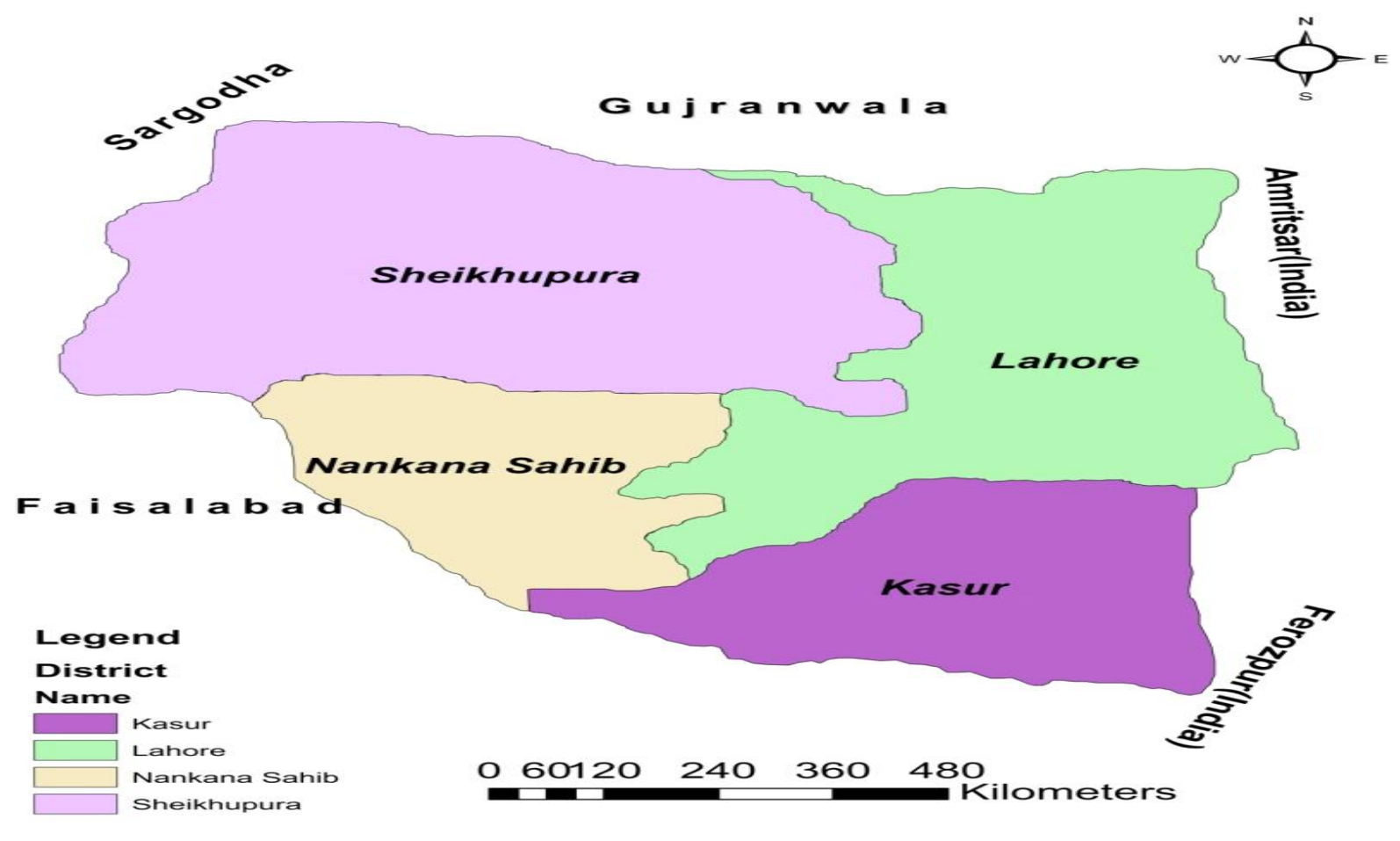

Figure 1: Map of the study area showing sampling sites of Kasur, Lahore, Nankana Sahib and Sheikhupura in Punjab Province, Pakistan (source: google maps).

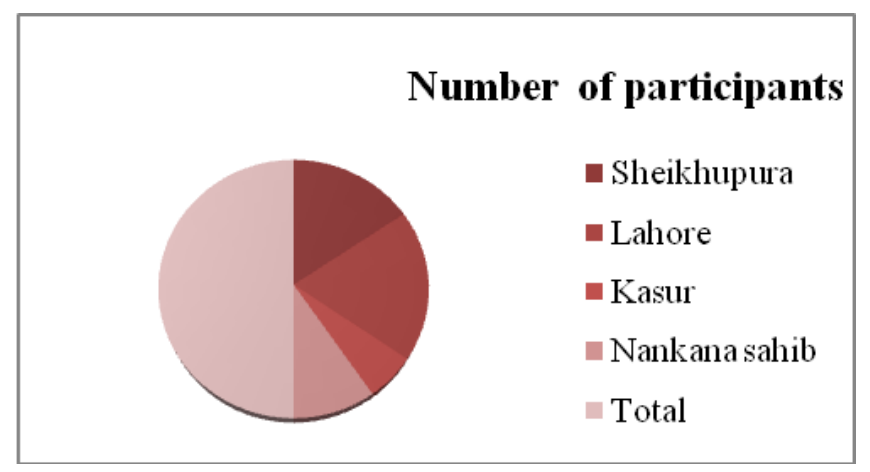

Figure 2: Pie chart showing proportion of participants from different districts of Punjab, Pakistan.

Inclusion criteria for the farmers was continuous exposure of insecticides spray such as chlorpyrifos (an organophosphate insecticide) and/or imidacloprid (a neonicotenoid insecticide). They are using these insectcides extensively in the agricultural fields by at least from the last five years. On the other hand, those individual were selected as sample for control/comparison group who were not involved in spray of pesticides.
The sample groups were matched on age and socioeconomic status. It was ensured that all subjects with apparent disease were excluded from research.

The study span stretched from October 2013 to September 2014.

First permission was taken from the Departmental Board of Studies and Advanced Studies and Research Board of GC University Lahore. A signed consent letter was taken from each individual participating in this study. They were told about the aims and objectives of the study and their role. They were explained that their blood sample (through syringe of $5 \mathrm{ml}$ ) will be taken, by using high standard procedure for scientific research, by a trained male nurse. They were further told that their participation in the study will be voluntary and they are participating in the research on their will and could withdraw from research if they want, at any instance during the study. Only those participants were included who gave written consent. Only fourteen participants (nine from study exposed group and five form control group) dropped - out during the study and were not included in the total head count.

$3 \mathrm{ml}$ of blood samples from all study individuals 
were collected through venipuncture into a gel - coated tube. Each tube was assigned an identification number, with sampling date, time, area and demographics of the sampled individuals (Figure $3-4$ ).

Blood serum was collected from the samples tubes which were without any anticoagulant. The blood samples were allowed to stand for few hours. The samples were then centrifuged at $4000 \mathrm{rpm}$ for $5-7$ minutes and serum was isolated. The serum was pipette out and stored at $-20^{\circ} \mathrm{C}$ for subsequent analyses.

For all the blood samples, same measurement Criteria was used; blood serum was analyzed to determine different biochemical parameters, such as urea, alanine transaminase (ALT), alkaline phosphate (ALP), serum creatinine, bilirubin, aspartate transaminase (AST) serum albumin, and total protein (TP) by following instructions of diagnostic kits using fully automatic chemistry analyzer (AU 480; Beckman Coulter). This study was performed at the certified pathological laboratory of Jinnah Hospital, Lahore, Pakistan.

$\mathrm{BChE}$ was determined by colorimetric method following the kit instructions of Randox (Cat No. CE190) using the semiautomatic analyzers (Metro Lab. 1600 DR) in a certified pathological laboratory of District headquarter hospital of Sheikhupura (DHQ - SKP), Punjab, Pakistan. Moreover all blood samples were preceded through same criteria for the measurement of BChE.

Collected data were statistically analyzed using Statistical Program for Social Sciences (SPSS, version 18). The frequencies, descriptive analysis, independent sample $t$-test, analysis of variance (ANOVA) were performed. Results were considered significant if $p$ values were $\leq 0.05$.
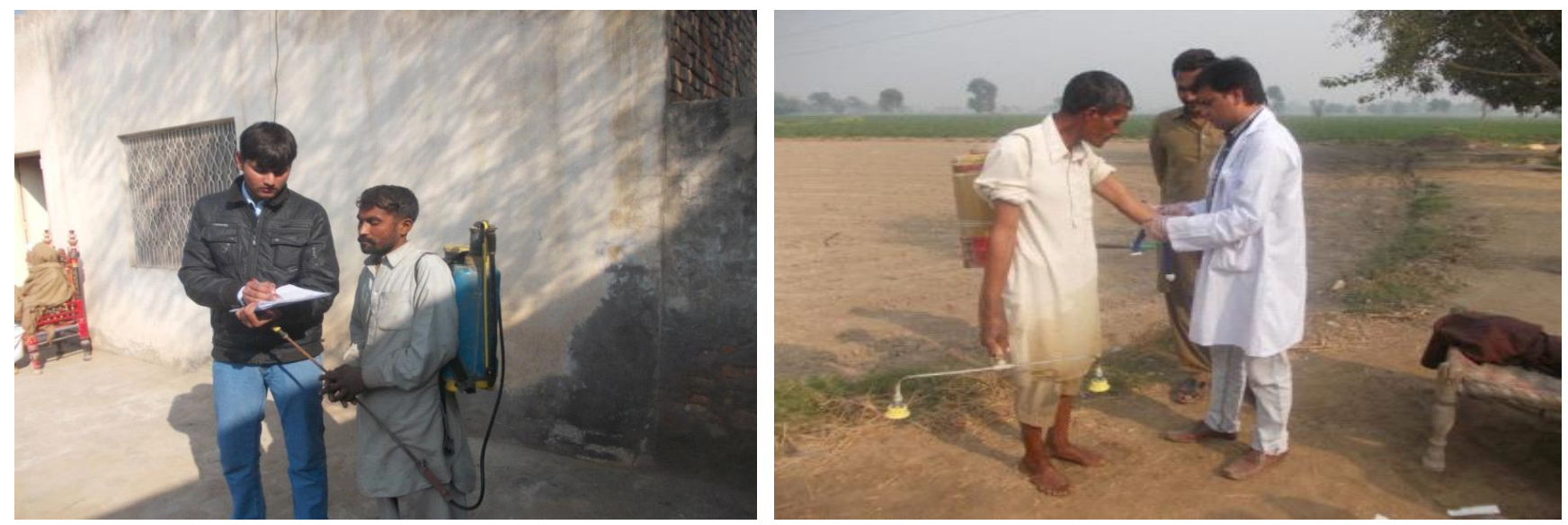

Figure 3-4: Interviews and physical examination of male farm workers and collection of Blood sample from a sprayer (all of farm workers are without any protective measures e.g. hand gloves, face, eyes, nose or mouth mask).

\section{Results}

No result was dropped out and Most of the farmers were found with poor protective measures. Only 5.5\% of the farmers used long shoes / boots and special spectacle during the spraying activity. Moreover, 92.5\% of farmers had never been used the special safety trouser. Only few farmers used cap/turban (6.6\%), gloves $(5.1 \%)$ or mouth mask $(5.1 \%)$ during the spray. Similarly, washing of hands, changing of cloths after spray and wear of gloves during the solution preparation was observed in $5.5 \%, 5.1 \%$ and $4.7 \%$ farmers, respectively. Very few farmers were aware of the preparation of pesticide dose (5.5\%), knowledge of mixing of pesticides $(5.5 \%)$, loading of pesticide in machine $(5.9 \%)$ and knowledge of maintenance of spray machine and other related equipment (5.7\%).

The Pesticides exposed farmers/spray operators had significantly higher levels of urea and ALT as compared to the control subjects moreover the levels of $\mathrm{BChE}$ (an already established marker for pesticide exposure) decreased significantly in farmers as compared to their respective controls. Similar trends were observed for albumin and total proteins (Table 1).

A significant increase in the levels of serum creatinine $(P=0.01)$ and AST $(P=0.01)$ among pesticides - exposed farmers/spray operators was recorded in the subjects who had never used the protective measures was observed in comparison to the subjects who occasionally, frequently, or always used the protective measures. However, there was notable decrease in the albumin, total proteins, and $\mathrm{BChE}(P=0.001)$ in the subjects who had never used the protective measures (Table 2). 
Table 1: Comparisons of biochemical parameters of pesticide exposed subjects (farmers) with pesticide non-exposed subjects (Independent $t$-test).

\begin{tabular}{|c|c|c|c|c|c|}
\hline & \multicolumn{5}{|c|}{ Farmers Versus Control } \\
\hline $\begin{array}{l}\text { Biochemical } \\
\text { Parameter's }\end{array}$ & NW & $\mathbf{M}$ & SD & $\mathbf{t}$ & $\mathbf{P}$ \\
\hline \multirow{2}{*}{$\begin{array}{l}\text { Urea } \\
\text { (MG/DL) }\end{array}$} & Farmer & 30.64 & 13.89 & \multirow{2}{*}{2.062} & \multirow{2}{*}{0.05} \\
\hline & Control & 27.23 & 9.97 & & \\
\hline \multirow{2}{*}{$\begin{array}{l}\text { ALT } \\
(\mathrm{SGPT} ; \mathrm{U} / \mathrm{L})\end{array}$} & Farmer & 26.25 & 20.43 & \multirow{2}{*}{2.435} & \multirow{2}{*}{0.01} \\
\hline & Control & 22.15 & 16.90 & & \\
\hline \multirow{2}{*}{$\begin{array}{l}\text { ALK. PHOSPHATE } \\
(\mathrm{U} / \mathrm{L})\end{array}$} & Farmer & 92.69 & 51.47 & \multirow{2}{*}{1.812} & \multirow{2}{*}{0.072} \\
\hline & Control & 96.28 & 39.05 & & \\
\hline \multirow{2}{*}{$\begin{array}{l}\text { S/Creatinine } \\
(\mathrm{MG} / \mathrm{DL})\end{array}$} & Farmer & 0.76 & 0.21 & \multirow{2}{*}{-.668} & \multirow{2}{*}{0.505} \\
\hline & Control & 0.75 & 0.22 & & \\
\hline \multirow{2}{*}{$\begin{array}{l}\text { Bilirubin T } \\
\text { (MG / DL) }\end{array}$} & Farmer & 0.51 & 0.24 & \multirow{2}{*}{.284} & \multirow{2}{*}{.0777} \\
\hline & Control & 0.50 & 0.20 & & \\
\hline \multirow{2}{*}{$\begin{array}{l}\text { AST } \\
(\mathrm{SGOT} ; \mathrm{U} / \mathrm{L})\end{array}$} & Farmer & 40.89 & 27.81 & \multirow{2}{*}{.117} & \multirow{2}{*}{.0907} \\
\hline & Control & 33.90 & 16.93 & & \\
\hline \multirow{2}{*}{$\begin{array}{l}\text { ALB } \\
(\mathrm{G} / \mathrm{DL})\end{array}$} & Farmer & 3.74 & 0.72 & \multirow{2}{*}{2.742} & \multirow{2}{*}{0.05} \\
\hline & Control & 4.39 & 0.38 & & \\
\hline \multirow{2}{*}{$\begin{array}{l}\mathrm{TP} \\
(\mathrm{G} / \mathrm{DL})\end{array}$} & Farmer & 7.21 & 1.39 & \multirow{2}{*}{-10.55} & \multirow{2}{*}{0.001} \\
\hline & Control & 8.60 & 1.08 & & \\
\hline \multirow{2}{*}{ BChE (U/L) } & Farmer & 4432.11 & 946.25 & \multirow{2}{*}{-25.83} & \multirow{2}{*}{0.001} \\
\hline & Control & 8025.69 & 1471.72 & & \\
\hline$n=339, \mathrm{~N}$ & (nature & vork); fal & $=256, \mathrm{c}$ & $\mathrm{ol}=83$ & \\
\hline
\end{tabular}

In Farm workers (having poor pesticide handling practices) albumin and total proteins levels declined significantly $(p=0.001)$ (Table 3$)$.

Majority of the studied subjects had dealt with pesticides for at least 5 years. In the farmers/spray operators, ALT, serum creatinine and AST levels were significantly higher $(p=0.01$ and $p=0.001$, respectively) but the serum albumin, total protein and $\mathrm{BChE}$ declined significantly $(p=0.001)$ in the subjects with higher duration of pesticide exposure (Table 4).

It was also noted that most of the farm workers $(73.8 \%)$ were smokers. In farmers/spray operators, due to exposure to pesticides, urea (smokers, mean $=31.83$ $\pm 15.52 \mathrm{mg} / \mathrm{dl}$ versus non-smokers, mean: $27.29 \pm$ 6.51, $p=0.05$ ), ALT (smokers, mean: $28.86 \pm 22.28 \mathrm{u} / 1$ versus non-smokers, mean: $21.24 \pm 17.09, p=0.01$ ), serum creatinine (smokers, mean: $43.18 \pm 29.87 \mathrm{mg} / \mathrm{dl}$ versus non-smokers, mean: $34.44 \pm 19.72 \mathrm{mg} / \mathrm{dl}, p=$ 0.05 ) and AST (smokers, mean: $31.83 \pm 15.52 \mathrm{u} / \mathrm{l}$ versus non-smokers, mean: $27.29 \pm 6.51 \mathrm{u} / \mathrm{l}, p=0.05$ ) lev- els increased significantly in smokers than in non-smokers; however, serum albumin (smokers, mean: $3.69 \pm$ $0.76 \mathrm{~g} / \mathrm{dl}$ versus non-smokers, mean: $3.88 \pm 0.58 \mathrm{~g} / \mathrm{dl}$, $p=0.05$ ), total protein (smokers, mean: $7.06 \pm 1.41$ $\mathrm{g} / \mathrm{dl}$ versus non-smokers, mean: $7.54 \pm 1.23 \mathrm{~g} / \mathrm{dl}, p=$ 0.01 ) and BChE (smokers, mean: $4106.80 \pm 851.85 \mathrm{u} / 1$ versus non-smokers, mean: $5349.80 \pm 484.14 \mathrm{u} / \mathrm{l}, p=$ 0.001) levels decreased (Table 5).

\section{Discussion}

Hazardous impacts on the health of the human population under investigation and exposed to pesticides, such as organophosphates, neonicotinoids, pyrethroids, carbamates and organochlorines etc. have been found. Various parameters have been discussed as follows.

Pesticide exposure in farmers seems to stimulate significant rise of urea and alanine transaminase 
Table 2: Comparison of biochemical parameters in relation to the protective measures use habits by the farm workers (one way ANOVA).

Significance confidence, $p \leq 0.05$ and 0.01

\begin{tabular}{|c|c|c|c|c|c|c|c|}
\hline $\begin{array}{l}\text { Biochemical } \\
\text { Parameters }\end{array}$ & Protective & $\mathbf{N}$ & \multicolumn{3}{|c|}{$\mathbf{M} \pm \mathbf{S D}$} & $\mathbf{F}$ & $\mathbf{P}$ \\
\hline \multirow{4}{*}{$\begin{array}{l}\text { S/ Creatinine } \\
\text { (MG/DL) }\end{array}$} & Never & 18 & 0.88 & \pm & 0.22 & \multirow{4}{*}{3.44} & \multirow{4}{*}{0.01} \\
\hline & Occasional & 27 & 0.82 & \pm & 0.21 & & \\
\hline & Frequent & 117 & 0.75 & \pm & 0.21 & & \\
\hline & Always & 94 & 0.73 & \pm & 0.21 & & \\
\hline \multirow{4}{*}{$\begin{array}{l}\text { AST } \\
\text { (SGOT; } \\
\text { U/L) }\end{array}$} & Never & 18 & 57.5 & \pm & 39.75 & \multirow{4}{*}{3.67} & \multirow{4}{*}{0.01} \\
\hline & Occasional & 27 & 48.54 & \pm & 41.29 & & \\
\hline & Frequent & 117 & 39.82 & \pm & 25.46 & & \\
\hline & Always & 94 & 36.84 & \pm & 21.39 & & \\
\hline \multirow{4}{*}{$\begin{array}{l}\text { Albumin } \\
\text { (G/DL) }\end{array}$} & Never & 18 & 2.93 & \pm & 0.85 & \multirow{4}{*}{16.78} & \multirow{4}{*}{0.001} \\
\hline & Occasional & 27 & 3.36 & \pm & 0.85 & & \\
\hline & Frequent & 117 & 3.74 & \pm & 0.71 & & \\
\hline & Always & 94 & 4.01 & \pm & 0.48 & & \\
\hline \multirow{4}{*}{$\begin{array}{l}\text { Total } \\
\text { Protein } \\
\text { (G/DL) }\end{array}$} & Never & 18 & 5.70 & \pm & 1.90 & \multirow{4}{*}{13.86} & \multirow{4}{*}{0.001} \\
\hline & Occasional & 27 & 1.70 & \pm & 1.08 & & \\
\hline & Frequent & 117 & 7.13 & \pm & 1.40 & & \\
\hline & Always & 94 & 7.68 & \pm & 1.02 & & \\
\hline \multirow{4}{*}{$\begin{array}{l}\mathrm{BChE} \\
(\mathrm{U} / \mathrm{L})\end{array}$} & Never & 18 & 2763.60 & \pm & 448.24 & \multirow{4}{*}{714.49} & \multirow{4}{*}{0.001} \\
\hline & Occasional & 27 & 3318.90 & \pm & 566.11 & & \\
\hline & Frequent & 117 & 4088.80 & \pm & 285.68 & & \\
\hline & Always & 94 & 5498.70 & \pm & 173.65 & & \\
\hline
\end{tabular}

Table 3: Analysis of the effect of pesticide handling expertise on the biochemical parameters of farm workers exposed to pesticides (one way ANOVA).

$N=256$; Pesticides usage expertise; very poor, 132, poor, 72, satisfactory, 38, good, 14) Significance confidence, $p \leq 0.05$ and 0.01

\begin{tabular}{|l|l|c|c|c|c|}
\hline $\begin{array}{l}\text { Biochemical } \\
\text { Parameters }\end{array}$ & $\begin{array}{l}\text { Pesticides } \\
\text { Usage } \\
\text { Expertise's }\end{array}$ & M & SD & F & $\boldsymbol{P}$ \\
\hline \multirow{4}{*}{$\begin{array}{l}\text { Albumin } \\
\text { (G/DL) }\end{array}$} & Very poor & 3.59 & 0.78 & & \\
\cline { 2 - 4 } & Poor & 3.85 & 0.71 & \multirow{2}{*}{4.12} & \multirow{2}{*}{0.001} \\
\cline { 2 - 4 } & Satisfactory & 3.94 & 0.49 & & \\
\cline { 2 - 4 } & Good & 4.01 & 0.49 & & \\
\hline \multirow{4}{*}{$\begin{array}{l}\text { TP } \\
\text { (G/DL) }\end{array}$} & Very poor & 6.86 & 1.48 & & \\
\cline { 2 - 4 } & Poor & 7.45 & 1.29 & \multirow{2}{*}{5.74} & \multirow{2}{*}{0.001} \\
\cline { 2 - 4 } & Satisfactory & 7.68 & 0.96 & & \\
\cline { 2 - 4 } & Good & 7.60 & 1.14 & & \\
\hline
\end{tabular}


Table 4: Study of biochemical parameters in farm workers in relation to exposure duration to pesticides (One way ANOVA).

\begin{tabular}{|c|c|c|c|c|c|c|}
\hline \multirow{2}{*}{ Biochemical Parameters } & \multirow{2}{*}{ Exposure Duration } & \multicolumn{3}{|c|}{ Farmer } & \multirow[t]{2}{*}{$\mathbf{F}$} & \multirow{2}{*}{ p } \\
\hline & & \multicolumn{3}{|c|}{$\mathrm{M} \pm \mathrm{SD}$} & & \\
\hline \multirow{4}{*}{ Urea (MG/DL) } & 15 years or more $* * * *$ & 32.45 & \pm & 11.31 & \multirow{4}{*}{2.172} & \multirow{4}{*}{.092} \\
\hline & 10 years or more ${ }^{* * *}$ & 34.78 & \pm & 18.55 & & \\
\hline & 5 years or more $* *$ & 31.23 & \pm & 14.98 & & \\
\hline & 1 years or $<5$ years $*$ & 28.2 & \pm & 9.97 & & \\
\hline \multirow{5}{*}{ ALT (SGPT; U/L) } & 15 years or more $* * * *$ & 39.18 & \pm & 30.52 & \multirow{5}{*}{3.385} & \multirow{5}{*}{0.01} \\
\hline & 10 years or more $* * *$ & 33.23 & \pm & 28.17 & & \\
\hline & 5 years or more $* *$ & 26.9 & \pm & 18.55 & & \\
\hline & 1 years or $<5$ years $*$ & 23.05 & \pm & 19.42 & & \\
\hline & Total & 26.86 & \pm & 21.28 & & \\
\hline \multirow{5}{*}{ Alk. Phosphate (U/L) } & 15 years or more $* * * *$ & 89.82 & \pm & 32.62 & \multirow{5}{*}{1.428} & \multirow{5}{*}{.235} \\
\hline & 10 years or more $* * *$ & 109.35 & \pm & 84.76 & & \\
\hline & 5 years or more ${ }^{* *}$ & 89.69 & \pm & 47.66 & & \\
\hline & 1 years or $<5$ years $*$ & 90.51 & \pm & 40 & & \\
\hline & Total & 92.69 & \pm & 51.47 & & \\
\hline \multirow{5}{*}{ S/Creatinine (MG/DL) } & 15 years or more $* * * *$ & 0.92 & \pm & 0.23 & \multirow{5}{*}{3.83} & \multirow{5}{*}{0.01} \\
\hline & 10 years or more ${ }^{* * *}$ & 0.83 & \pm & 0.2 & & \\
\hline & 5 years or more ${ }^{* *}$ & 0.75 & \pm & 0.21 & & \\
\hline & 1 years or $<5$ years $*$ & 0.73 & \pm & 0.21 & & \\
\hline & Total & 0.76 & \pm & 0.21 & & \\
\hline \multirow{5}{*}{ Bilirubin T (MG/DL) } & 15 years or more $* * * *$ & 0.46 & \pm & 0.21 & \multirow{5}{*}{1.496} & \multirow{5}{*}{.216} \\
\hline & 10 years or more $* * *$ & 0.57 & \pm & 0.21 & & \\
\hline & 5 years or more ${ }^{* *}$ & 0.51 & \pm & 0.25 & & \\
\hline & 1 years or $<5$ years $*$ & 0.48 & \pm & 0.22 & & \\
\hline & Total & 0.51 & \pm & 0.24 & & \\
\hline \multirow{5}{*}{ AST (SGOT; U/L) } & 15 years or more $* * * *$ & 63.45 & \pm & 47.74 & \multirow{5}{*}{5.132} & \multirow{5}{*}{0.001} \\
\hline & 10 years or more $* * *$ & 51.16 & \pm & 40.55 & & \\
\hline & 5 years or more** & 39.11 & \pm & 23.74 & & \\
\hline & 1 years or $<5$ years $*$ & 36.66 & \pm & 21.35 & & \\
\hline & Total & 40.89 & \pm & 27.81 & & \\
\hline \multirow{4}{*}{ Serum Albumin (G/DL) } & 15 years or more $* * * *$ & 2.79 & \pm & 0.85 & \multirow{4}{*}{16.539} & \multirow{4}{*}{0.001} \\
\hline & 10 years or more ${ }^{* * *}$ & 3.34 & \pm & 0.84 & & \\
\hline & 5 years or more ${ }^{* *}$ & 3.73 & \pm & 0.72 & & \\
\hline & 1 years or $<5$ years $*$ & 4 & \pm & 0.48 & & \\
\hline
\end{tabular}




\begin{tabular}{|c|c|c|c|c|c|c|}
\hline & Total & 3.74 & \pm & 0.72 & & \\
\hline \multirow{5}{*}{ Total Protein (G/DL) } & 15 years or more $* * * *$ & 4.66 & \pm & 1.19 & \multirow{5}{*}{21.216} & \multirow{5}{*}{0.001} \\
\hline & 10 years or more $* * *$ & 6.84 & \pm & 1.21 & & \\
\hline & 5 years or more $* *$ & 7.12 & \pm & 1.41 & & \\
\hline & 1 years or $<5$ years $*$ & 7.68 & \pm & 1.02 & & \\
\hline & Total & 7.19 & \pm & 1.38 & & \\
\hline \multirow{5}{*}{ BChE (U/L) } & 15 years or more $* * * *$ & 2465.91 & \pm & 301.51 & \multirow{5}{*}{728.50} & \multirow{5}{*}{0.001} \\
\hline & 10 years or more $* * *$ & 3394.94 & \pm & 745.52 & & \\
\hline & 5 years or more $* *$ & 4054.47 & \pm & 93.38 & & \\
\hline & 1 years or $<5$ years $*$ & 5499.04 & \pm & 172.75 & & \\
\hline & Total & 4432.11 & \pm & 946.25 & & \\
\hline
\end{tabular}

(Farmers; Total $\mathrm{n}=256, * * * *=11, * * *=35, * *=115, *=5 \quad$ Significance confidence, $p \leq 0.05$ and 0.01

$\mathrm{NW}=$ nature of work, ALT $($ SGPT $)=$ alanine transaminase, AST $($ SGOT $)=$ aspartate transaminase, ALB = Serum Albumin, Bilirubin T = Bilirubin Total, S/Creatinine $=$ Serum Creatinine, TP $=$ Total Protein, BChE $=$ Butyrylcholinesterase

Table 5: Comparison of biochemical changes between the Smokers and non-smoker groups of farm workers.

\begin{tabular}{|c|c|c|c|c|c|c|}
\hline Biochemical Parameters & Smoking Habits & \multicolumn{3}{|c|}{$\mathrm{M} \pm \mathrm{SD}$} & F & $\mathbf{P}$ \\
\hline \multirow{2}{*}{ Urea (MG/DL) } & Smokers & 31.83 & \pm & 15.52 & \multirow{2}{*}{5.371} & \multirow{2}{*}{0.05} \\
\hline & Non-smokers & 27.29 & \pm & 6.51 & & \\
\hline \multirow{2}{*}{ ALT (SGPT;U/ L) } & Smokers & 28.86 & \pm & 22.28 & \multirow{2}{*}{6.473} & \multirow{2}{*}{0.01} \\
\hline & Non-smokers & 21.24 & \pm & 17.09 & & \\
\hline \multirow{2}{*}{ S/ Creatinine (MG/DL) } & Smokers & 0.78 & \pm & 0.21 & \multirow{2}{*}{3.322} & \multirow{2}{*}{0.05} \\
\hline & Non-smokers & 0.72 & \pm & 0.21 & & \\
\hline \multirow{2}{*}{ AST (SGOT;U/L) } & Smokers & 43.18 & \pm & 29.87 & \multirow{2}{*}{4.963} & \multirow{2}{*}{0.05} \\
\hline & Non-smokers & 34.44 & \pm & 19.72 & & \\
\hline \multirow{2}{*}{ Serum Albumin (G/DL) } & Smokers & 3.69 & \pm & 0.76 & \multirow{2}{*}{3.346} & \multirow{2}{*}{0.05} \\
\hline & Non-smokers & 3.88 & \pm & 0.58 & & \\
\hline \multirow{2}{*}{ Total Protein (G/DL) } & Smokers & 7.06 & \pm & 1.41 & \multirow{2}{*}{5.951} & \multirow{2}{*}{0.01} \\
\hline & Non-smokers & 7.54 & \pm & 1.23 & & \\
\hline \multirow[t]{2}{*}{$\mathrm{BChE}(\mathrm{U} / \mathrm{L})$} & Smokers & 4106.80 & \pm & 851.85 & \multirow{2}{*}{127.81} & \multirow{2}{*}{0.001} \\
\hline & Non-smokers & 5349.80 & \pm & 484.14 & & \\
\hline
\end{tabular}

$N=256 ;$ smokers $=189 ; \quad$ Non-smokers $=67 ; \quad$ Significance confidence, $p \leq 0.05$ and 0.01

(ALT), whereas there was a tendency of decline in the levels of albumin and total proteins in the pesticides exposed population (farmers) compared to non-exposed subjects (Table 1). These findings are in agreement with a number of previously reported similar stu dies. ${ }^{26-30}$ A recent study, using mice as a model animal, revealed that deltamethrin (a synthetic pyrethroidpesticide) caused decrease in total proteins. ${ }^{31}$ The dec- 
rease of serum proteins, especially albumin, might be due to alteration in protein metabolism of free amino acids and their production in liver under the influence of pesticides. ${ }^{32}$ Another explanation of protein decline may be the result of protein loss either due to protein synthesis reduction/degradation or increase in the proteiolytic activity. ${ }^{33}$ Protein metabolism results in the production of urea and creatinine as waste products that are needed to be excreted through the kidney. The marked increase in levels of serum urea and creatinine are indicators of kidney function impairment. ${ }^{34}$ The potential increase in the levels of ALT indicated the damages to the liver. ${ }^{35}$ This implies that the pesticides used in the study are organophosphates; neonicotinoids, pyrethroids, carbamates and organochlorines etc have exerted suppressive impact on protein anabolism as well as resulted in the deteriorating functions of liver and kidney.

Butyrylcholinesterase (BChE) is a non-specific enzyme that can cause hydrolyses of a lot of diverse choline esters. BChE is reliable biomarker and confirmed indicator of organophosphate exposure. ${ }^{36}$ In humans, primarily it is present in the liver. ${ }^{37}$ and is determined by the BCHE gene. ${ }^{38}$ The decline in BChE level can cause the delay in the metabolism of some of clinically significant compounds, such as succinylcholine, procaine, mivacurium, cocaineand heroin, etc. ${ }^{39}$

Depressed level of butyrylcholinesterase (BChE) levels in spray operators/farmers in comparison to their respective controls in this study confirms the adverse impact of exposure of organophosphates to these populations. This theory is further strengthened by the findings significant variations in the values those using protective measures as compared to those not using any of these. Similar findings have already been reported in other related studies previously conducted on farmers handling pesticides. ${ }^{40-44}$ For instance, in a pesticide - exposed population in India, significant decrease in cholinesterase level was reported. ${ }^{45}$ Several other studies have also suggested a decrease in BChE level in response to exposure to organophosphates. ${ }^{46,47}$ Similarly, in other parts of the developing world, including Mexico, Kenya, and Bangladesh, similar findings have been reported. ${ }^{45,48,49}$ Varying responses of the populations exposed to insecticides by varying degree indicate that the impact rendered on part of these insecticides depends on a number of factors, such as the duration of exposure, the use of protective measures, etc.

One of the major causes of this scenario is that there is no strict implementation of "personal protection guidelines" by the local government or any other relevant authority in Punjab. These observations reveal that most of the farmers never use any protection (Figure 3-4).

Among the pesticide-exposed farmers/spray operators, a significant increase in serum creatinine and AST but on the other hand, significant decrease in albumin, total proteins, and BChE (Table 2) again show even worse situation of health profile of this population. This implies that the risk of pesticide toxicity is directly proportional to the extent of exposure, No or inappropriate use of protective measure involved in his business lead to more influx of the insecticides in the body, either through inhalation, skin contact or even through exposed living surface, such as eyes, etc.; this might lead to altered physiological and biochemical processes.

Similar findings have been suggested by the previous studies concerning insecticide toxicity. ${ }^{50}$

Similar trend was also reported by a study carried out in Egypt where significant incidence of health related problems were reported in agricultural community. ${ }^{51,52,53}$

Another study also pointed out that the incidence of pesticide exposure increased among workers who had not followed instructions / guidelines for proper handling of pesticides. ${ }^{15,54,3}$

Significantly altered biochemical responses in the populations under investigation with more number of years $(<10)$ and particularly that BChE levels (Table 4) support the idea that the toxicity of insecticide increases with the passage of time. These findings are in agreement with the previously undertaken study on agricultural workers in Kenya, where cholinesterase inhibition was recorded due to prolonged exposure of the workers to pesticides. ${ }^{49}$ Similarly the elevated levels of ALT in more exposed population in our study endorse the previously reported similar findings. ${ }^{55}$

Elevated levels of vital biochemical indicators, such as urea, ALT, serum creatinine, and AST and the depressed values of serum albumin, total proteins, and BChE levels (Table 5) in smokers (comprising of major proportion of the studied population; $84 \%$ of farmers). These findings are also confirmed by already reported assumptions. ${ }^{56,57,27,58,59}$ This implies that tobacco smoking stresses vital physiological mechanisms and puts the body the body on elevated risk of insectcide toxicity. 


\section{Conclusion}

Several biomarkers have shown the possible hazards of pesticides to farmer's health than controls. However, Farmers with less exposure duration to pesticides, good pesticides handling practices and nonsmoking habits do not suffered much than as compare to farmers with poor pesticide handling practices and greater exposure duration.

\section{References}

1. Oerke EC, Dehne HW. Safeguarding production - losses in major crops and the role of crop protection. Crop protection, 2004 Apr. 30; 23 (4): 275-85.

2. Boxall RA. Post-harvest losses to insects - a world overview. International Biodeterioration and Biodegradation, 2001 Dec. 31; 48 (1): 137-52.

3. Damalas CA, Eleftherohorinos IG. Pesticide exposure, safety issues, and risk assessment indicators. International journal of environmental research and public health, 2011 May 6; 8 (5): 1402-19.

4. Tariq MI, Afzal S, Hussain I, Sultana N. Pesticides exposure in Pakistan: A review. Environment International, 2007 Nov. 30; 33 (8): 1107-22.

5. Malik A, Ojha P, Singh KP. Levels and distribution of persistent organochlorine pesticide residues in water and sediments of Gomti River (India) - a tributary of the Ganges River. Environmental Monitoring and Assessment, 2009 Jan. 1; 148 (1-4): 421-35.

6. Rao P, Arcury TA, Quandt SA, Doran A. North Carolina growers' and extension agents' perceptions of Latino farm worker pesticide exposure. Human Organization, 2004 Jun. 1; 63 (2): 151-61.

7. O'Connell PJ, Guilbault GG. Future trends in biosensor research. Analytical letters, 2001 Apr. 30; 34 (7): 106378.

8. Konstantinova M, Kocova M, Charlier C, Bourguignon J. Organochloride pesticides in Macedonian girls with premature sexual development. Balkan Journal of Medical Genetics, 2007 Apr. 1; 10 (1): 43-8.

9. Srivastava AK, Gupta BN, Bihari V, Mathur N, Srivastava LP, Pangtey BS, Bharti RS, Kumar P. Clinical, bioche-mical and neurobehavioural studies of workers engaged in the manufacture of quinalphos. Food and chemical toxicology, 2000 Jan. 31; 38 (1): 65-9.

10. Kesavachandran C, Singh VK, Mathur N, Rastogi SK, Siddiqui MK, Reddy MM, Bharti RS, Khan AM. Possible mechanism of pesticide toxicity - related oxidative stress leading to airway narrowing. Redox Report, 2006 Aug. 1; 11 (4): 159-62.

11. Harley KG, Marks AR, Bradman A, Barr DB, Eskenazi B. DDT exposure, work in agriculture, and time to pregnancy among farm workers in California. Journal of occupational and environmental medicine/American College of Occupational and Environmental Medicine, 2008 Dec; 50 (12): 1335.

12. Wesseling C, Aragón A, Castillo L, Corriols M, Chaverri F, Cruz ED, Keifer M, Monge P, Partanen TJ, Ruepert C, De Joode BV. Hazardous pesticides in Central America. International journal of occupational and environmental health, 2001 Oct. 1; 7 (4): 287-94.

13. Konradsen F, van der Hoek W, Cole DC, Hutchinson G, Daisley H, Singh S, Eddleston M. Reducing acute poisoning in developing countries - options for restricting the availability of pesticides. Toxicology, 2003 Nov. 5; 192 (2): 249-61.

14. Coronado GD, Holte SE, Vigoren EM, Griffith WC, Barr DB, Faustman EM, Thompson B. Do workplace and home protective practices protect farm workers? Findings from the For Healthy Kids Study. Journal of occupational and environmental medicine/American College of Occupational and Environmental Medicine, 2012 Sep; 54 (9).

15. Jaga K, Dharmani C. Sources of exposure to and public health implications of organophosphate pesticides. Revistapanamericana de saludpública, 2003 Sep; 14 (3): 171-85.

16. Lesmes - Fabian C, García - Santos G, Leuenberger F, Nuyttens D, Binder CR. Dermal exposure assessment of pesticide use: The case of sprayers in potato farms in the Colombian highlands. Science of the Total Environment, 2012 Jul. 15; 430: 202-8.

17. Pimentel D, Acquay H, Biltonen M, Rice P, Silva M, Nelson J, Lipner V, Giordano S, Horowitz A, D'amore M. Environmental and economic costs of pesticide use. Bio Science, 1992 Nov. 1; 42 (10): 750-60.

18. Lewalter J, Leng G. Consideration of individual susceptibility in adverse pesticide effects. Toxicology letters, 1999 Jun. 30; 107 (1): 131-44.

19. Carpy SA, Kobel W, Doe J. Health risk of low - dose pesticides mixtures: a review of the 1985 - 1998 literature on combination toxicology and health risk assessment. Journal of Toxicology and Environmental Health Part B: Critical Reviews, 2000 Jan. 1; 3 (1): 1-25.

20. Khan MF, Khan MI, Aslam M, Naqvi SN. Study of cholinesterase level in blood of cotton field workers exposed to pesticides. Journal of Baqai Medical University, 2000; 3: 12-6.

21. Mehboob S, Sultana S, Al-Akel AS, Al-Balawi AK, AlMisned F, Zubair M. Pesticide residues in flesh of Cirrhinusmrigala collected from a commercial farm and river Chenab at Trimu Head, Jhang. Pakistan Journal of Zoology, 2011; 43 (1): 97-101.

22. Khan MZ, Naqvi SN, Khan MF, Rahila T, Ahmad I, Farina F. Induced effect of Biosal on GOT and GPT in wildlife species of Agama Lizard Calotes versicolor. Pakistan J. Biol. Sci. 2002; 4 (6): 611-2.

23. Azmi MA, Naqvi SN, Azmi MA, Aslam M. Effect of pesticide residues on health and different enzyme levels 
in the blood of farm workers from Gadap (rural area) Karachi-Pakistan. Chemosphere. 2006 Sep. 30; 64 (10): 1739-44.

24. Remor AP, Totti CC, Moreira DA, Dutra GP, Heuser VD, Boeira JM. Occupational exposure of farm workers to pesticides: biochemical parameters and evaluation of genotoxicity. Environment International, 2009 Feb. 28; 35 (2): 273-8.

25. Fareed M, Pathak MK, Bihari V, Kamal R, Srivastava AK, Kesavachandran CN. Correction: Adverse Respiratory Health and Hematological Alterations among Agricultural Workers Occupationally Exposed to Organophosphate Pesticides: A Cross - Sectional Study in North India. PloS one, 2013; 8 (8).

26. Shakoori AR, Aziz F, Alam J, Ali SS. Toxic effects of Talstar, a new synthetic pyrethroid, on blood and liver of rabbit. Pakistan Journal of Zoology, 1990; 22 (3): 289-300.

27. Yousef MI, El-Demerdash FM, Kamel KI, Al-Salhen $\mathrm{KS}$. Changes in some hematological and biochemical indices of rabbits induced by isoflavones and cypermethrin. Toxicology, 2003 Aug. 1; 189 (3): 223-34.

28. Patil JA, Patil AJ, Govindwar SP. Biochemical effects of various pesticides on sprayers of grape gardens. Indian journal of clinical biochemistry, 2003 Jul. 1; 18 (2): 16-22.

29. Bhalli JA, Khan QM, Haq MA, Khalid AM, Nasim A. Cytogenetic analysis of Pakistani individuals occupationally exposed to pesticides in a pesticide production industry. Mutagenesis, 2006 Mar. 1; 21 (2): 143-8.

30. Al-Sarar AS, Bakr YA, Hussein HI, Bayoumi AE. Hematological and Biochemical Alterations in Occupational!) Pesticides - Exposed Workers of Riyadh Municipality, Kingdom of Saudi Arabia. Research Journal of Environmental Toxicology, 2009; 3 (4): 179-85.

31. Desai BN. Effects of agro chemicals on the physiological stress on teleost fish.

32. Atia MA. Risk assessment of occupational exposure to pesticides. Earth Environ Sci. 2006; 3: 349-62.

33. Yeragi SG, Rana AM, Koli VA. Effect of pesticides on protein metabolism of mud skipper Boleophthalmusdussumieri. Journal of Ecotoxicology and Environmental Monitoring, 2003 Jul; 13 (3): 211-4.

34. Garba SH, Adelaiye AB, Mshelia LY. Histopathological and biochemical changes in the rats kidney following exposure to a pyrethroid based mosquito coil. J. Appl. Sci. Res. 2007; 3 (12): 1788-93.

35. Raurich JM, Pérez O, Llompart - Pou JA, Ibáñez J, Ayestarán I, Pérez - Bárcena J. Incidence and outcome of ischemic hepatitis complicating septic shock. Hepatology Research, 2009 Jul. 1; 39 (7): 700-5.

36.Narra MR. Tissue-specific recovery of oxidative and antioxidant effects of chlorpyrifos in the freshwater crab, Barytelphusaguerini. Archives of environmental contamination and toxicology, 2014 Aug. 1; 67 (2): 158-66.
37. Jasmin L. "Cholinesterase - blood". University of Maryland Medical Center, 2013.

38. Allderdice PW, Gardner HA, Galutira D, Lockridge O, Ladu BN, McAlpine PJ. The cloned butyrylcholinesterase (BCHE) gene maps to a single chromosome site, 3q26. Genomics, 1991 Oct. 31; 11 (2): 452-4.

39. Otitoju O, Onwurah IN. Biomarkers of Pesticide - Contaminated Environment. INTECH Open Access Publisher; 2011.

40. Bushnell PJ, Kelly KL, Ward TR. Repeated inhibition of cholinesterase by chlorpyrifos in rats: behavioral, neurochemical and pharmacological indices of tolerance. Journal of Pharmacology and Experimental Therapeutics, 1994 Jul. 1; 270 (1): 15-25.

41. Venkataraman BV, Rani MN, Andrade C, JOSEPH T. Correlation of time course of blood cholinesterase activity and toxic manifestations of acute methylparathion in antidote treated rats. Indian J Physiol Phannacol. 1994; 38 (3): 214-6.

42. Husin LS, Uttaman A, Hisham HJ, Hussain IH, Jamil MR. The effect of pesticide on the activity of serum cholinesterase and current perception threshold on the paddy farmers in the Muda agricultural development area, MADA, Kedah, Malaysia. The Medical journal of Malaysia, 1999 Sep; 54 (3): 320-4.

43. Araoud M, Neffeti F, Douki W, Hfaiedh HB, Akrout M, Hassine M, Najjar MF, Kenani A. Adverse effects of pesticides on biochemical and haematological parameters in Tunisian agricultural workers. Journal of Exposure Science and Environmental Epidemiology, 2012 May 1; 22 (3): 243-7.

44. Hernández AF, Gil F, Lacasaña M, Rodríguez - Barranco M, Tsatsakis AM, Requena M, Parrón T, Alarcón R. Pesticide exposure and genetic variation in xenobiotic - metabolizing enzymes interact to induce biochemical liver damage. Food and chemical toxicology, 2013 Nov. 30; 61: 144-51.

45. Singh S, Kumar V, Thakur S, Banerjee BD, Chandna S, Rautela RS, Grover SS, Rawat DS, Pasha ST, Jain SK, Ichhpujani RL. DNA damage and cholinesterase activity in occupational workers exposed to pesticides. Environmental toxicology and pharmacology, 2011 Mar. 31; 31 (2): 278-85.

46. Khan DA, Bhatti MM, Khan FA, Naqvi ST, Karam A. Adverse effects of pesticides residues on biochemical markers in Pakistani tobacco farmers. International journal of clinical and experimental medicine, 2008; 1 (3): 274.

47. Khan DA, Shabbir S, Majid M, Naqvi TA, Khan FA. Risk assessment of pesticide exposure on health of Pakistani tobacco farmers. Journal of Exposure Science and Environmental Epidemiology. 2010 Mar 1; 20 (2): 196-204.

48. Rojas - García AE, Medina - Díaz IM, de Lourdes Robledo - Marenco M, Barrón - Vivanco BS, Girón Pérez MI, Velázquez - Fernández JB, González - Arias 
CA, Albores - Medina A, Quintanilla - Vega B, Ostrosky - Wegman P, Rojas - García MC. Hematological, biochemical effects, and self - reported symptoms in pesticide retailers. Journal of Occupational and Environmental Medicine, 2011 May 1; 53 (5): 517-21.

49. Ohayo - Mitoko GJ, Kromhout H, Simwa JM, Boleij JS, Heederik D. Self reported symptoms and inhibition of acetylcholinesterase activity among Kenyan agricultural workers. Occupational and environmental medicine, 2000 Mar. 1; 57 (3): 195-200.

50. Yassin MM, Mourad TA, Safi JM. Knowledge, attitude, practice, and toxicity symptoms associated with pesticide use among farm workers in the Gaza Strip. Occupational and environmental medicine. 2002 Jun. 1; 59 (6): 387-93.

51. Tchounwou PB, Ashour BA, Moreland - Young C, Ragheb DA, Romeh AA, Goma EA, El-Sheikh S, Lidell FP, Ibitayo O, Assad JC. Health risk assessment of pesticide usage in Menia El-Kamh Province of Sharkia Governorate in Egypt. International Journal of Molecular Sciences, 2002 Oct. 31; 3 (10): 1082-94.

52. Fianko JR, Donkor A, Lowor ST, Yeboah PO, Glover ET, Adom T, Faanu A. Health risk associated with pesticide contamination of fish from the Densu River Basin in Ghana. Journal of Environmental Protection, 2011 Mar. 21; 2 (02): 115.

53. Khan AA, Shah MA, Rahman SU. Occupational exposure to pesticides and its effects on health status of workers in Swat, Khyber Pakhtunkhwa, Pakistan. Journal of Biology and Life Sciences, 2013 Jul. 1; 4 (2): 43.
54. Hernández AF, Gómez MA, Pérez V, García - Lario JV, Pena G, Gil F, López O, Rodrigo L, Pino G, Pla A. Influence of exposure to pesticides on serum components and enzyme activities of cytotoxicity among intensive agriculture farmers. Environmental research, 2006 Sep. 30; 102 (1): 70-6.

55. Demos K, Sazakli E, Jelastopulu E, Charokopos N, Ellul J, Leotsinidis M. Does Farming Have an Effect on Health Status? A Comparison Study in West Greece. International journal of environmental research and public health, 2013 Feb. 26; 10 (3): 776-92.

56. Abbassy MA, Marei AE, Al-Ashkar MA, Mossa AT. Adverse biochemical effects of various pesticides on sprayers of cotton fields in El-Behira Governorate, Egypt. Biomedicine and Aging Pathology, 2014 Sep. 30; 4 (3): 251-6.

57. Ebuehi OA, Akinwande AI, Famuyiwa OO, Uzodinma EO, Adebayo OA, Onwumere OA, Masade ON, Aiyesimoju B. Effect of marijuana smoking on blood chemistry and serum biogenic amines concentrations in Humans. Nigerian Journal of Health and Biomedical Sciences, 2005 May 5; 4 (1): 20-4.

58. Asif M, Sajjad K, Zubaida U, Arif M. Effect of cigarette smoking based on hematological parameters: comparison between male smokers and nonsmokers. Turkish Journal of Biochemistry - Turk J Biochem. 2013 Jan. 1; 38 (1): 75-80.

59. Inal B, Hacıbekiroglu T, Cavus B, Musaoglu Z, Demir H, Karadag B. Effects of smoking on healthy young men's hematologic parameters. 